\title{
Kurumlar Sosyolojisi Perspektifinden Pandemi Döneminde Kurumsallaşma Pratikleri
} Mehmet ÖZCAN ${ }^{1}$

\section{$\ddot{O} z$}

$\mathrm{Bu}$ çalışma pandemi döneminde toplumsal sistemin kurumsal işleyişinde ortaya çıkan meydan okumalara karşı gelişen kurumsallaşma pratikleri üzerine bir değerlendirmedir. Toplumsal sistem karşılıklı etkileşim içerisinde olan kurumların yapılaşmasıdır. Toplumsal olarak kurumlar toplumu oluşturan bireylerin ihtiyaçlarını karşılamaya dönük olarak ortaya çıkan temel unsurlardır. Değişme ya da kriz dönemlerinde cari kurumsal sistem genellikle bireylerin ihtiyaçlarının karşılanmasında yetersiz kalır. Toplumsal sistem bu durumda kendisini yeniden üreterek sorunları aşabilir. Bu çerçevede toplumsal sistemin meydan okumalara karşı ve toplumun yeniden üretiminin temel unsuru olarak kurumsallaşmalar ortaya çıkar. Pandemi döneminde birçok alanda krizler ortaya çıktı. Toplumsal sistemde ağırlıklı olarak; ekonomi, eğitim ve sağlık gibi kurumsal alanlarda kurumsallaşma pratiklerinin ortaya çıktığı belirtilmiştir. Çalışma toplumsal sistemlerin yeni kurumsallaşma pratikleri çerçevesinde ortaya çıkan dönüşümünü anlamayı hedeflemektedir.

\author{
Anahtar Sözcükler \\ toplum \\ kurumsallaşma \\ pandemi \\ değişim
}

Makale Hakkında

Geliş Tarihi: 28.07.2021

Kabul Tarihi: 12.08.2021

Doi:

10.20304/humanitas.975568

\section{Institutionalization Practices during the Pandemic Period from the Perspective of Institutions Sociology}

\begin{abstract}
This study is an evaluation on the institutionalization practices that have developed against the challenges that arise in the institutional functioning of the social system during the pandemic period. Socially, institutions are the basic elements that emerge in order to meet the needs of the individuals who make up the society. In times of change or crisis, the current institutional system often falls short of meeting the needs of individuals. In this case, the social system can overcome the problems by reproducing itself. In this framework, institutionalizations emerge as the basic element of the social system's challenges and the reproduction of society. In the social system mainly; It has been stated that institutionalization practices have emerged in institutional areas such as economy, education and health. The study aims to understand the transformation that has emerged within the framework of the new institutionalization practices of social systems.
\end{abstract}

\author{
Keywords \\ society \\ institutionalization \\ pandemic \\ transformation
}

About Article

Received: 28.07.2021

Accepted: 12.08.2021

Doi:

10.20304/humanitas.975568

\footnotetext{
1 Öğr. Gör. Dr., Ankara Hacı Bayram Veli Üniversitesi, Polatlı Sosyal Bilimler MYO, Ankara/Türkiye, mehmet.ozcan@hbv.edu.tr, ORCID: 0000-0001-7350-7855
} 


\section{Giriş}

Sosyolojinin toplumsal sistemin yapısını anlamaya dönük olarak ileri sürdügü anahtar kavramlardan birisi kurumdur. Toplumsal sistemlerin bireyleri belirli temel hedeflere sahip olacak şekilde organize etmeleri gerekir. Bireyler kültürel, ekonomik ve politik olarak yekpare özelliklere sahip değildirler. Toplum bu yönüyle bünyesinde doğal olarak farklılıkları barındıran bir yapıdır. Bu çerçevede toplumsal sistemin bu farklılıklara dayalı olarak bireylere bir eşgüdüm kazandırması gerekmektedir. Toplumsal sistem bu farklılıkları organize etmesi ve toplumsal varoluşu biçimlendirmesi kurumlar aracılığıyla gerçekleşir. Kurum kavramı toplumsal yapının sistematik olarak bireyleri biçimlendirerek onlara amaçlar kazandırması ve organize etmesini sağlayan temel mekanizmalar olarak karşılık bulur. Toplumsal değişme ve kriz dönemlerinde bu kurumların yapısı da değişime uğrar. Ayrıca yeni kurum ve kurumsallaşmalar da ortaya çıktığı gibi bazı kurumlar da ortadan kalkar.

\section{Kurumlar ve Toplumsal Varoluş}

Toplumsal varoluş farkl1lıklara dayalı şekilde kendini ortaya koyarken bu varoluşa ortak hedefler ve çıkarlar kazandırılması çerçevesinde işlevsel olarak ortaya çıkan organize toplumsal etkileşimlerin biçimlendirilmesini sosyolojik çerçevede kurum kavramı karşılar. Sosyolojik olarak kurum toplumsal hayatın temel bir görümüdür. Toplumsal sistemler kurumlar olmaksızın bir hayatiyet kazanamazlar. Kurumlar toplumların ihtiyaçları çerçevesinde ortaya çıkarlar ya da değişime uğrarlar. Toplumsal varoluşa yön veren normlar, değerler ve kolektif davranışlar da sosyolojik olarak kurum kavramında karşılık bulur. Toplumsal kurumlar bireylerin varoluşu için bir şemsiye vazifesi görür. Toplumsal eylemin normatif değerinin meşruiyetini kurumlar sağlar. Bireylerin etkileşim ve pratiklerinin temel kurallarının kaynağı da kurumlar olarak karşımıza çıkar. Bu çerçevede normlar toplumsal sistemin temel amaç ve hedeflerini belirleyerek yapıya temel gerçekliğini kazandırırlar. Kurumlar insanların temel ihtiyaçlarını karşılamaya dönük olarak bu normlar sistemini üretirler. Temel ihtiyaç ve beklentiler bu anlamda yapı tarafından karşılanır. Kurumlar sosyolojisi temelinde toplumsal sistemler; aile, din, eğitim, siyaset ve ekonomi olmak üzere insan varoluşunun temel ekseni etrafında kurumları bünyelerinde barındırırlar. Kurumlar sosyolojisi bu bağlamda ortaya çıkan kurumsal yapıları anlamaya çalışır. Ayrıca kurumların temel yapıları ve iç dinamikleri de bu anlama faaliyetinin bir parçası olarak karşımıza çıkar. Kurumlar sosyolojisi toplumsal yapının organizasyon karakteri ve yapının dayandığı normlar dünyası hakkında temel bir perspektife sahip olunmasına katkı sağlayarak sistemin rasyonel bir görünüm ve işleyişe kavuşmasını da temin eder. Kurumlar toplumsal varoluşun çerçevesi 
olarak bireyleri bu varoluşun tabiatına entegre eder. Kurumların bir şemsiye olarak bu anlamda temel işlevlerinden birisi de bu entegrasyondur. Toplumsal olarak kültürel, politik ve ekonomik farklılıkların sistem tarafından üretilen normlar ve değerler çerçevesinde entegrasyonu böylece kaçınılmaz olur. Yine aynı şekilde toplumsal yapıdaki kurumlar arası etkileşim ve ilişki de kurumlar sosyolojisinin konusu içerisindedir. Her kurum bir biçimde eşgüdüm ve uyum içinde belirli değer ve normlara dayalı olarak oluşan bir bütündür. Bütünlük kurumlar arası toplumsal zeminde de karşılık bulmasıyla uyumlu bir toplumsal düzenin varlık kazanması gerçekleşmiş olur. $\mathrm{Bu}$ anlamda toplumsal düzen farklılıkları böylece uyum içerisinde bir varoluşun parçaları olarak örgütlenmiş olur.

Toplum bir bütün olarak bünyesinde kurumların işlevlerine dayalı olarak bir gerçeklik kazanır. $\mathrm{Bu}$ işlevlerin yerine getirilmesiyle sosyal sistem bir anlam kazanır. Kurumsal işlevlerin yerine getirilmemesi durumunda sosyal sistem kurumsal işlevleri yeniden tanımlayarak kurumları yapısal olarak yeniden düzenler. Gelişen ihtiyaçlara sosyal sistem yeni kurumsallaşma pratikleri çerçevesinde cevap verir. Bu yeniden kurumsallaşma pratikleri bazen kurumsal işlevlerde bir yenilenme bazen de farklı bir kurumsallaşma olarak kendini ortaya koyar (Fichter, 1990, s. 110).

Toplumsal sistemde kurumlar karşılıklı bir etkileşim içerisinde bir yapı ortaya koyarlar. Bir kurum diğer kurumlardan ayrı olarak bir varlık kazanamaz. Kurumlar bu anlamda diğer kurumlardan özerk olarak bir varlık ortaya koyamazlar. Kurumlar arası karşılıklı etkileşim ve uyum da bir sorun ortaya çıktığında her kurum bundan etkilenir. Bir kurumda ortaya çıkan işlevsel hasar diğer kurumlara da sirayet edecektir. Bu durumda kurumların yaşadığı krizler ve işlevsel hasarlar bir toplumsal krizi de tetikleyebilir (Bal, 2020, s. 46).

Kurumların toplumsal işleyiş üzerindeki etkisi, kendisini toplumsal hayatta gerçekleştirilen organizasyon ve düzenlemeler ile ortaya koyar. Toplumsal işleyiş kurumsal organizasyon bağlamında kaos düzene dönüşür. Toplumsal yapının sürekliliği kurumlar aracılığıyla sağlanır. Kurumların toplumsal sistemler için temel bir koşul olarak anlamı bir yönüyle burada ortaya çıkar. Toplum bir süreklilik sağlanmadığı zaman yıkılma durumunu yaşamaktan kurtulamaz. Toplumsal kurumlar, normlarda ve değerlerde sağladıkları standardizasyon ile toplumsal sürekliliğin bir başka yönünü ortaya koyarlar (Akyüz, 2008, s. 46).

Kurumlar toplumsal hayatın sürekliliğine sundukları katkının yanında değişim dönemlerinde edindikleri kültürel karakter ile engelleyici bir yapının öğesi olarak ortaya 
çıkabilirler. Bunun yanında normlar ve değerler aracılığıyla sağladıkları rutinizasyon yaşanılan ve gelmekte olan değişimi görmeye ve yakalamaya imkân verebilir (Akyüz, 2008, s. 44).

\section{Sosyolojik Olarak Kurumsallaşma}

Toplumsal sistemler canlı organizmalar olarak değişim sürecinden kendilerini yalıtamazlar. Değişim olgusu toplumsal sistemler üzerinde yıkıcı etkiler de ortaya koyabilir. Bazı toplumsal sistemler bu değişime ayak uyduramayıp ortadan kalkarlar. Bazıları da bu değişime göre kendilerini yeniden organize edip varlıklarını sürdürmeye çalışırlar. Günümüz dünyasında değişim tarihte olmadığı kadar dinamik ve kalıcı etkiler ortaya koyuyor. Toplumsal sistemler ya da kurumsal pratikler bu değişime gösterdikleri tutum ile varlıklarını sürdürebilirler (Bal, 2020, s.56). Değişim ya da kriz dönemlerinde bu süreçlerin biraz daha can alıcı biçimde kendisini gösterdiği söylenebilir. Normal dönemlerde toplumsal istikrar değişim ya da krizin meydan okumaları ile karşı karşıya kalmadığı için böyle bir durum ortaya çıkmaz. Yakın zamanda ve halen içinde yaşadığımız Covid-19 pandemisi toplumsal sistemler için bu anlamda krizi tetikleyen bir gelişme olmuştur. Eğitim, sağlık, ekonomi, siyaset gibi birçok kurum üzerinde covid-19 pandemisinin kalıcı etkilerin ortaya çıkmasına yol açtığı söylenebilir. Toplumsal sistemler ve kurumlar bu kriz sebebiyle yapısal bir meydan okumayla karşılaştılar. Toplumsal sistemlerin bu meydan okuma ile baş etmek için geleneksel olandan farklı kurumsallaşma pratiklerinin gelişmesini sağlayarak bu durumu aşmaya çalıştıkları söylenebilir.

Genel olarak toplumsal sistemler için kurumsallaşma ile belirlenen amaçlar çerçevesinde normlar ve değerlere dayalı olarak teşekkül eden yapılar olarak tanımlanabilir. Bireyler bu normlar ve değerlere dayalı olarak bir düzenlilik içerisinde davranış ve tutumlar ortaya koyarlar. Bu yönüyle Akyüz’e göre (2008), “kurumsallaştırma, tutum ve davranışların belirli formlar içerisinde gerçekleştirilmesi, bu davranış ve isteklerin toplumsal bir amaç olacak biçime kavuşturularak somutlaştırılması" olarak görülebilir (Akyüz, 2008, s. 15).

Toplumsal sistemler için kurumsallaşma değişimin yakalanması için önemli bir araç olarak karşımıza çıkar. Yeni değer ve normların kurumsal yapıya dahil edilmesi kurumsallaşma ile gerçekleştirilir. İnsanların tutum ve davranışları da sistem üzerinde bir etki ortaya koyar. Ortak güdülere dayalı olarak gerçekleşen davranışlar da bir kurumsallaşmayı doğurabilir. Berger ve Luckman'a göre (2008), dışsallaşma yani kişinin kendisi ve toplumsal alan üzerinde ilişkide olduğu bireylerin hareket halinde olması, objektifleştirme gerçekleştirilen hareketlerin dişsallaşması ve içselleştirme de nesnelleşen diş çevrenin bireyler 
tarafından özümsenmesi olarak üç aşamada kurumsallaşmanın kavranabileceğini ileri sürer (Berger ve Luckman, 2008, s. 78). Bu anlamda herkes tarafindan benimsenen değerler ve normlar çerçevesinde tutum ve davranışlar geliştirme süreci olarak görülebilir.

Kurumsallaşma bireylerin beklenti ve talepleri bağlamında toplumsal alan ile etkileşim sürecini yaşamaları neticesinde ortaya çıkan eylemlerin belirli bir rutine dönüşmesi olarak görülebilir. Kurumsallaşma bu yönüyle bireyi aşan bir çerçeve kazanmalıdır. Toplumsal olarak bireyleri aşan bir yapının ortaya çıkması aynı zamanda belirli norm ve değerlerin de bu sürecin temel taşıyıcısı olma işlevini öne çıkarır. Tarihsel olarak toplumlar ortaya koydukları kurumsallaştırmalarla varlıklarını sürdürürler. Kurumların bireye dışsal olması onun öznesinin insan olduğu gerçeğini ortadan kaldırmaz. Bu yönüyle kurumsallaşma toplumsal yapının oluşumu olarak görülebilir. Burada anlaşılması gereken temel husus değişim ya da kriz sürecinde kurumsallaşmanın yeniden kurumsallaşma boyutu içerdiğidir. Yeniden kurumsallaşma norm ve değer dünyasına bağlı olarak gelişen beklenti ve ihtiyaçların karşılanmasına dönük toplumsal çevrede ortaya çıkan bir farklılaşma durumudur. $\mathrm{Bu}$ farklılaşma olagelen toplumsal dinamiklerin değişimidir. Eğitim, ekonomi ve diğer kurumsal davranış ve pratiklerin dönüşümünü içeren bir sürecin yeniden şekillenmesidir. Toplumsal alan ya da çevre bir meydan okuma ile karşılaştığında kurumlar cevap veremediğinde yeni kurumsallaşmaya giden süreç ortaya çıkar. Tarihsel olarak bu tür gelişmeler çevreden kaynaklı olarak büyük ölçüde bir karşılık bulur. Kurumsallaşma ile birlikte yeni norm ve değerler de şekillenmeye başlar. Bu yeni norm ve değerler kurumsallaşmayı sağlamaya dönük olarak bireylerin davranışlarını çerçevelemeye başlar.

Birey ve toplum arasındaki uyumu besleyen temel olgulardan birisi olarak kurumsallaşmadır. Hem bireyin hem toplumun varlıklarını sürdürebilmeleri için bu anlamda değişim sürecinde kurumsallaşmayı göz önünde bulundurmaları, birey ve toplumun uyumunun sağlanması gerektiği düşüncesi ön plana çıkar. Kurumsallaşma olgusu bu bağlamda toplumun sürekliliği, amaç ve hedeflerin gerçekleştirilmesi için temel bir süreç olarak toplumsal sistemlerde karşımıza çıkar. Bu çerçevede kurumsallaşma olgusu yapısal olarak temel bazı formel tutum ve davranışların bir kurallar bütününe dönüşmesi olarak değerlendirilebilir.

Toplumsal sistemlerde kurumlar varoluşu organize eder. Bir anlamda belirsizlik bir düzene dönüştürülür. Toplumun sürekliliği içerisinde yeniden kurumsallaşma pratikleri sürekli toplumsal alanda karşımıza çıkar. Bu toplumun statik bir yapı olmadığı ile ilgili olarak karşımıza çıkar. Değişim ve kriz toplumsal sistemler için kendilerini yenilemelerini zorunlu 
kılar. Çevrenin dinamikleri ile uyum içerisinde olarak toplumsal sistemler bu krizleri yönetebilirler (Smith, 2011, s. 202).

Bireyin değişim sürecinde çevreye uyumunu sağlayan temel mekanizma bu anlamda kurumsallaşma pratikleridir. Toplumsal çevre bireyin uyumunu sağlayacak mekanizmalar üreterek kendisini sürdürür.

Kurumsallaşmada öne çıkan temel konulardan birisi de mevcut toplumsal sistemin kurumsal yapısının yeni gelişmelere cevap üretememesi durumudur. Kurumsallaşma mevcut toplumsal birimin hangi toplumsal kuruma ait olduğuna bakılmaksızın bir yenilenme ve kendini üretme stratejisi olarak değerlendirilebilir. Reform ve değişim tartışmaları yeni kurumsallaşma arayışının söylemi olarak karşımıza çıkar. Bireylerin beklentileri ya da toplumsal çevrede meydana gelen farklılaşmanın göz ardı edilmesi bile yeniden kurumsallaşmanın etkisinin gücünü perdeleyemez.

\section{Pandemi Dönemi Kurumsallaşma Pratikleri}

Tarihsel olarak ortaya çıkan sosyal kırılmalar toplum hayatının birçok alanında yeni gelişmelerin devreye girmesine kaynaklık eder. Sosyal değişmeler ağırlıklı olarak bu tür gelişmeler sonrası sahne alır. Toplumlar statik olarak değerlendirilse de sürekli olarak bir değişim sürecinin içerisindedirler. Fakat tarihsel bir kriz neticesinde ortaya çıkan değişim süreçleri toplum ve bireyler için kaçınılmaz etkiler ortaya koyacaktır. Toplumsal sistemin cari yapısının mevcut değişim sürecine hem uyum sağlaması hem de kendisini yeniden üretmesi gerekir. Toplumun yapısal dönüşümü bu bağlamda değişme beklentilerini karşılayacak bir biçimde ortaya çıkar. Yeni kurumsallaşma pratikleri toplumsal dönüşümün yapısal karakterini de gösterir. Kurumsallaşmanın dinamikleri bu boyutuyla ele alındığında gelmekte olan toplumsal iklimin kültürel özelliklerinin etkilerini açığa vurur. Bununla birlikte sağlık kurumları bütün toplumsal tarihsel sistemlerde önemli görülmüştür. Fakat sadece modernite ile birlikte sağlık olgusu yapısal etkinlik düzeyini yakalamıştır. Modern toplum tıp ve klinik pratikleri çerçevesinde sağlığı endüstri toplumunun işleyişinde temel bir paradigma olarak ön plana çıkartmıştır (Foucault, 2006, s. 56). Küresel düzeyde pandeminin toplumsal sistemler üzerinde katastrofik bir etki ortaya koyması da bu çerçevede anlaşılabilir. Çalışma hayatı ve toplumsal varoluş hiçbir toplumsal sistemde görülmediği kadar sağlığın etkisi altındadır. Bu yönüyle de etkisinin ağır olduğu söylenebilir.

Kriz dönemleri çerçevesinde Covid-19 salgınının küresel düzeyde toplumsal sistemler üzerinde bu düzeyde ağır etkisinin olduğunu söylenebilir. Sosyal ve ekonomik sistemlerin bu süreçten ağır bir biçimde etkilendi. Hatta ileri kapitalist toplumlar yaşadıkları 
meydan okuma karşısında vatandaşlarına karşılıksız nakit yardımında bulunmak zorunda kaldılar. Yaşanılan salgın sosyal sistemleri köklü bir biçimde etkiledi. Salgının toplumsal hayatın üzerindeki köklü etkisi “'kapanma”' kavramında kendisini gösterdi. Kapanma modern toplumun görünür bütün hareketlilik ve katılım mekanizmalarını altüst etti. İnsanlar adeta 'eve döndü’ler. Modern kapitalizmin hareket ve enerji üzerine kurulu metafiğizi yerini terkedilmiş hayalet şehirlere bıraktı. Bireyler ve toplumsal sistemler tarihin akışı içerisinde adeta yeni bir aşamaya geçtikleri düşüncesini içselleştirdiler (Demir, 2020, s. 78).

Modern zamanların toplumsal hareketlilik dünyası bireyleri ve toplumları adeta bir seferberlik halinde 'ev dişında bir varoluşa' yönelmişti. Modern zamanların mitolojik dünyasında köyler ve kırsal hayat şehirlerin cazibesiyle terkedilmiş alanlar olarak tarihte yerini almıştı. Cadde ya da bulvar modern insanın varoluşunda ayinsel mekanlar olarak yer aldı. Modern toplum kitlelerin seferber edildiği bir varoluş dünyasıdır. Kitleler çalışma alanlarında, caddelerde, eğitim kurumlarında ya da yollarda araçlar içerisinde durmadan hareket eden insan kütleleri modernliğin dolaysız resmi olarak görülebilir. Salgın döneminde devreye giren kapanma bu manzarayı adeta tersine çevirdi. Küresel düzeyde dünya üzerinde bir yavaşlamayı beraberinde getirdi. Kapitalizmin mabetleri olan üretim ve tüketim mekanları da bu kapanmadan payını aldı. Eğitim kurumları, okul ve üniversite kampüsleri sessizliğe gömüldü. Toplum ve birey görünürlüğün gerisine çekildi. Ağır savaş koşullarına benzer toplumsal tedbirler politik iktidarlar tarafindan devreye sokuldu.

Kriz ve felaket sosyolojisi toplumların bu süreçlerde ürettikleri politikaların kurumsal kültürün bir parçası olduğunu ifade eder (Beck, 2008, s. 78). Kültürel, politik ve ekonomik yapılar bu süreçten etkilenirken aynı zamanda baş etmenin mekanizmalarını da hızla kurumsallaştırmaya çalışırlar. Salgın döneminde toplumsal kurumsal mekanizmalar kapanmanın ve sosyal hareketliliğin gerilemesiyle yeniden kurumsallaşma pratiklerini devreye girmesine yol açtı. Toplumsal tarihte yeni kurumsallaşma perspektifi yaşanılan değişimin de ipuçlarını vermesi açısından önem arz etmektedir. Toplumsal sistemlerin kriz dönemleri tasavvurlarına göre bir gelecek perspektifine sahip oldukları söylenebilir. Salgın döneminin ortaya çıkardığı toplumsal kriz sistemlerin teknoloji temelli bir kurumsallaşma pratiklerini öne çıkardıkları görülmektedir. Burada teknoloji temelli dönüşüm dijitalleşme olarak değerlendirilebilir. Dijitalleşme toplumsal hayatın network ya da sayısallaştırılarak bilgisayar, tablet, akıllı telefon ve teknolojik araçlar üzerinden bir akış halinde sanallaşarak gerçekleşmesidir (Beck, 1992, s. 56). Günümüzdeki kurumsallaşma pratiklerinin temelinde teknolojik bir dönüşüm olduğu görülmektedir. Bu teknolojik dönüşüm kurumsallaşma 
Özcan, M. (2021). Kurumlar sosyolojisi perspektifinden pandemi döneminde kurumsallaşma pratikleri. Humanitas, 9(18), 208-220.

pratiklerindeki farklılaşmanın da anahtarı olarak karşımıza çıkmaktadır. Kurumsallaşma pratiklerinde ortaya çıkan durum insan ve mekan unsurunun normatifliğinin geri planda kalmasına yol açmaktadır.

Kurumsallaşma pratiklerini ekonomi, eğitim ve sağlık gibi kurumsal yapıların üzerinden bu sürecin kavraması mümkündür. Bu üç kurum yaşanan salgın ve buna bağlı olarak ortaya çıkan krizin açık bir biçimde yeniden kurumsallaşmada kendini gösterdiği alanlardir.

\section{Ekonomide Kurumsallaşma Pratikleri}

Endüstri toplumunun işleyişinde ön plana çıan temel kurumların başında ekonomi gelmektedir. Geleneksel toplumlara nazaran modern toplum sistematik üretime ve tüketime dayalı bir sistemdir. Ekonomik mekanizmalardaki aksamalar bütün düzeni etkileyerek geri dönüşü olmayan sonuçlara sebebiyet verebilir. Tarihsel olarak modern toplum üretim paradigmasına bağlı eşsiz bir toplum örneğidir. Bu anlamda toplumsal hareketler, politik yönelimler, sistemlerin yükseliş ve düşüşü ekonomideki dalgalanmalara bağlıdır. Toplumsal felaket dönemlerinde ortaya çıkan temel kaygı hayatta kalma refleksidir. Toplumlar bu dönemlerde gelecek konusunda ortaya çıan belirsizliklerle baş etmenin yollarını ararlar. Salgın başladığında kapanma olgusu devreye girdi. Ekonomi yavaşladı, üretim durma noktasına geldi. İnsanlar ihtiyaçlarının karşılanması çerçevesinde kapanma ile birlikte bu ihtiyaçların tedariki konusunda sorunlar ortaya çıktı. Kapanma ile birlikte Covid-19'un bulaşma riskleri insanları alışveriş merkezlerinden uzak kalmaya yönlendirdi. Ekonomik olarak pazar insanlar ile malların karşılaştı̆̆ ayinsel bir mekan olarak dünya ekonomi tarihinde yerini almıştır. Pazar ekonomisi olarak anlamanın ötesinde 'mahalle pazarı' pratiği bu değerlendirmeye karşıllk gelir. Dijitalleşme ile birlikte metaya dokunmadan alışveriş yapma süreçleri başlamışıı. Fakat ekonomik olarak sanal alışveriş ile birlikte market alışverişlerinin yoğunluk kazandığı bir süreci devreye soktu. Salgının temel sonuçlarından bir tanesi dijitalleşmeye bağlı olarak gelişen mekanizmaların insan ve toplum hayatında kurumsallaşmaya dönüştüğü söylenebilir. Ekonomik kurumsallaşma pratikleri salgın döneminde toplumsal hayatta güçlü bir biçimde yerini aldı. Bir anlamda bu kurumsallaşmalar toplumsallaştı. Domatesi koklayarak alan bir toplumun bireyleri sanal sipariş ile domates almaya başladı. Muhtemelen bu farklılaşma temel bir dönüşümün de işaret fişeği olarak görülebilir. Metanın aşkınlığı kendisini dokunulmaz bir aşamaya getirerek taçlandırmıştır. Toplumsal olarak ekonomik kurumsallaşma pratiği sanal olarak verilen siparişin kısa zaman içerisinde kapı zilini çalarak gelmesidir. Burada bir davranış değişikliğinin de ortaya çıktığını 
söylenebilir. Yığınların sessizliği adeta alışveriş merkezlerini de sessizliğe gömerek sanal uzama dönmüştür. Dijitalin merkezsizleştirdiği dünyaya sanal alışveriş de eklenmiştir (Erşen, 2020, s. 76). Alışveriş sürecinde metaya dokunmak bir nostaljiye dönüştü. Ekonomik kurumsallaşma pratiğinin tek ihtiyaç duyduğu bir akıllı cihaz ve buna bağlı dijital bankacılığın entegrasyonu ile bir app olacaktır. Burada kutsal kelime app olacaktır. Sanal uzamda milyonlarca ürünü ziyaret edebileceğiniz app’lerin gerçekliği bu kurumsallaşmayı göstermektedir.

\section{Eğitimde Kurumsallaşma Pratikleri}

Modern toplumda eğitim ulus devletler eliyle toplumun bütün katmanlarını kuşatacak şekilde kurumsallaştırılmıştır. Temel eğitim bir toplumsal seferberlik hali olarak kodlanmıştır. Okul sistemi tarihte görülmemiş bir biçimde modern toplumda yaygın ve örgün bir kurum olarak yerini aldı. Toplumsal sosyalizasyon işlevinin ötesinde endüstri toplumunun nitelikli işgücünün sağlanması için temel bir kurum olarak toplumsal sistemde istihdam edilmiştir. Okul sistemsel ideolojinin toplumsallaştırılması yanında üretim paradigmasının da temel kurumudur.

Salgın döneminde kapanma sonrası dünyanın birçok yerinde okulların zilleri sustu. Kampüslerin kapısına adeta kilit vuruldu. Kapanma döneminde eğitim faaliyetlerinin uzaktan yürütülmesi kurumsallaştırılmaya başlandı. Uzaktan eğitimin tarihi yeni olmasa da küresel düzeyde tek eğitim aracı olarak dijital araçlara dayalı olarak küresel düzeyde yaygınlık kazandı (İşman, 2008, s. 89). Adeta binalar ve eğitim araçları kıyıya vuran gemi enkazına dönüştü. Öğrencisi ve öğretmeniyle 'eğitim ordusu 'kapanma ile görünmez olmuş ve toplumsal sahneden çekildi. Salgın döneminin kurumsallaşma pratiği olarak uzaktan eğitim toplumsal alanda yerini almış oldu. Uzaktan eğitim ile birlikte temel toplumsal bir davranış olan okulun da toplumsal sahnedeki yeri yeniden düşünülmeye başlandi. Okulun bir toplumsallaşma aygıtı olarak rölü azaldı denebilir. Toplumsal ilişkilerde mesafenin artması kurumsal düzeyde okul pratiğini etkiledi. Bununla birlikte uzaktan eğitim öğretim mekanizmasını mikrolalaştırarak mesafeleri azaltarak network aracılığıyla merkezsizleştirdi. $\mathrm{Bu}$ durumun uzun vadede toplumsal etkileri kendisini ortaya koyacaktır. Uzaktan eğitim zamanı ve mekanı yatay ve dikey olarak aşan bir eğitim pratiği olarak toplumsal bir kurumsallaşmaya işaret etmektedir.

Uzaktan eğitim kurum ötesi bir kurumsallaşma olarak eğitim faaliyetinin mekanlara hatta zaman çizelgesine bağlı olmadan gerçekleştirilmesini tetikleyen bir mekanizmanın işlevselleşmesi olarak görülebilir. Kurumsallaşma olarak uzaktan eğitim temelde merkezsiz 
bir süreci öne çıkarmaktadır. Toplumsal mekân olarak okul ya da aktör olarak eğitimcinin de konumunu altüst ederek geleneksel olarak ortaya çıkan pratiği dönüştürmektedir. Dijital araçlarla gerçekleşen eğitim süreçleri eğitimi yapı söküme uğratmaktadır. Uzaktan eğitim, eğitimde merkezi politik bagajları yüklenmeye devam etse de eğitimin dijitalleşmesi yolunda okulun mekân olarak varlığını sınırlandırmıştır. Okulun varlığını sınırlasa da eğitimin toplumsal bütün çevreye ulaşmasına imkân veren bir kapasiteyi de seferber ettiği söylenebilir. Dijital akıllı araçlar, internet olduğunda eğitimin bütün sınırları aşacağı bir potansiyeli de taşıdığı söylenebilir.

\section{Sağlık Temelli Kurumsallaşma Pratikleri}

Covid -19 salgını sağlık olgusu üzerinden gelişerek bütün diğer toplumsal kurum ve varoluşu etkiledi. Salgın sağlık kaynaklı olarak geliştiği için toplumsal düzeni etkisi altına alması neredeyse kendiliğinden gerçekleşti. Salgın ile birlikte toplumsal sahnede beliren temel görüntü 'maske' olgusu oldu. Aynı şekilde toplumsal etkileşimin 'mesafe' vurgusuyla yeniden kurumsallaşmasına kaynaklık etti. Modern toplumun ikincil ilişkileri zaten maskeli ve mesafeliydi. Artık bu durumun ötesinde sosyalin sınırlı bir düzleme çekilmesi gerekliliği dolaşıma sokuldu. Salgın toplumsal sistemlerin yeniden düzenleneceğinin açık bir işaretini bu göstergeler üzerinden gösterdi. Buna benzer birçok gelişme salgın döneminin gösterileri olarak tarihte yerini aldı. Fakat salgın döneminin sağlık temelli kurumsallaşma pratiği 'aşı pasaportu 'küresel düzeyde bir karşılık buldu. Yirminci yüzyıl halk sağlığındaki temel gelişme bebeklerin dünyaya gelişi ile birlikte aşıları almaya başlamaları olmuştu. Dünyanın birçok yerinde çocukların aşı kartı denilen bir kimlikleri de ortaya çıktı. Fakat salgın döneminde ortaya çıkan ve her geçen gün devletlerin ortak politikası haline gelmekte olan aşı pasaportu gibi bir gerçeklik üretmedi (Özkan, 2021, s. 78). Aşı pasaportu ya da aşı kimliği tamamen covid-19 pandemisinin küresel düzeyde karşılık bulmasına kaynaklık eden bir sonuç olarak karşımıza çıkmaktadır. Aşı pasaportu toplumsal sistemlerde yeni bir kurumsallaşma pratiği olarak karşımıza çıkmaktadır. Yasal hakları kullanmanın bir ön şartı olarak kurumsal pratikte yerini alması gerektiği yaklaşımları bunu açıkça göstermektedir. Dünyanın birçok yerinde aşı pasaportuna olan ilgi küresel toplumun temel bir kurumsallaşma pratiği olarak karşımıza çıkmaktadır. Uluslararası vatandaş olmanın temel kurallarından biri olarak sosyal haklar tarihine aşı pasaportunun girdiği söylenebilir (Aktan, 2021, s. 1). Krizin sağlık üzerinden gelişmesi etkisini yoğunlaştırdı. Pandemi böylece bütün toplumsal sistemeler üzerinde küresel bir etki ortaya koydu. 


\section{Sonuç ve Değerlendirme}

Toplumsal sistemler beklenti ve ihtiyaçlar kurumları inşa ederek karşılamaya çalışırlar. Kurumsallaşma sosyolojik olarak bu sürece karşılık gelir. Değişim ve kriz dönemleri toplumsal sistemlerin kendilerini sürdürmelerinin temel bir aracı olarak genellikle yeni kurumsallaşma pratikleri ortaya çıkar. Yaşadığımız dönemde toplumsal sistemler sağlık temelli bir kriz ile karşılaştılar. Sağlık temelli olarak bu krizin gelişmesi bütün kurumlar üzerinde bir etkinin ortaya çıkmasına yol açtı. Toplumsal hareketliliğinin sınırlandırılması ve kapanmanın meşruiyeti böylece kendiliğinden bir karşılık buldu. Yeni kurumsallaşma pratikleri hem toplumsal sistemin yeniden üretimini sağlarken hem de bireyin sisteme uyumunu sağlayacak yapılar olarak değerlendirilebilir. Kriz ve değişim dönemlerinde cari yapıların sistemdeki fonksiyonellikleri bazen yetersizlikleri üretirler. Bu çerçevede yeni kurumsallaşmalar ortaya çıkar. Kurumsal dönüşümler akabinde kültürel sistemlerde kendisini yeniden üretir (Williams, 1983, s. 89) Ekonomi, eğitim ve sağlık temelli olarak ortaya çıkan yeni gelişmeler kurumsallaşmalara kaynaklık etti. Ekonomi ve eğitim alanında ortaya çıkan kurumsallaşma pratikleri geleneksel işleyişin farklılaşmasına yol açacak bir nitelik ortaya koymaktadır. Network sistemine dayalı olarak iki kurum düzeyinde köklü bir farklılaşma ve deneyim ortaya çıktı. Milyonları bünyesine katarak sürdürülen bir eğitim faaliyetinin yanında eğitim kurumunun fiziksel yapıları bir anda adeta network sistemiyle yerini merkezsiz bir sanal yapıya bıraktı. Ekonomi de benzer bir biçimde arz ve talebin sanal mecraya dayalı olarak gerçekleşmesine yol açtı. Modern bir ayin olarak adeta bireylerin alışveriş merkezleri ziyaretleri yerini sanal olana bıraktı. Sağlık alanında gelişen 'aşı pasaportu' da bütün bu network sisteminin bireyi görünmez kılan yönüne karşılık bir kontrol mekanizmasının kurumsallaşma pratiği olarak değerlendirilebilir. Aș1 pasaportu küresel düzeyde politik olarak bulduğu destek ile bir tür kontrol ve aidiyet kimliğinin unsuru olarak karşılık bulduğu söylenebilir. Hatta ekonomi ve eğitim kurumları alanındaki gelişmeleri tamamlayıcı nitelikte bir araç olarak aşı pasaportunun geliştiği söylenebilir. Aşı pasaportu sağlık temelli bir gelişme olarak küresel ve yerel düzeyde hareketliliği kontrol etmeye dayalı bir kurumsallaşma pratiği boyutunu taşıdığı söylenebilir. Covid-19 pandemisiyle birlikte dünya değişirken toplumsal kurumlar da böylece değişiyor. Pandeminin görünür en belirgin sembolleri maske ve mesafe olarak kendini gösterse de buna en son aşı da eklendi. Maske ve mesafe toplumsal yapı temelli ilişkilerin tamamıyla dönüşmesini içeren göstergelerdir. Bu durumun modern toplumun ikincil ilişkilere dayalı toplumsal etkileşimin sınırları modelini de aşan bir sosyal mesafe tahayyülünü tetiklediği söylenebilir. Toplumsal etkileşimin farklılaşmasını öne çıkaran unsurlar olarak değerlendirilebilir. Covid-19 pandemisi bu yönüyle toplumsal 
Özcan, M. (2021). Kurumlar sosyolojisi perspektifinden pandemi döneminde kurumsallaşma pratikleri. Humanitas, 9(18), 208-220.

etkileşimde öne çıkan 'soğuk ve uzak' ikincil ilişki tarzının da ötesini öne çıkarmaktadır. Maske öznenin anonimleşmesini öne çıkarırken mesafe bu anonimliğin tamamıyla bir kayboluşa dönüşmesini tetiklemektedir. Toplumsal sistemlerin tarihin bu kriz momentinde değişimin yeni bir aşamasına tanıklık etmekten kaçınmalarının imkansız olduğu apaçıktır. Fakat pandeminin görünen toplumsal ve politik etkilerine dayalı sonuçlarının tamamıyla kendini gösterdiği söylenemez. Değişme süreçlerinin toplumsal sistemler için kısa sürede etkisini göstermesi beklenemez. Değişimin kalıcı etkileri uzun vadede kendisini ortaya koyacaktır. 


\section{Kaynakça}

Aktan, S. (2021, 4 Haziran). Avrupa Birliği’nde aşı pasaportu 7 üye ülke tarafından kullanılmaya başlandı. Euronews Türkçe. https://tr.euronews.com/2021/06/04/avrupabirligi-nde-as-pasaportu-7-uye-ulke-taraf-ndan-kullan-lmaya-basland

Akyüz, H. (2008). Kurumlar sosyolojisi. Ankara: Siyasal Kitabevi.

Bal, H. (2020). Kurumlar sosyolojisi. İstanbul: Sentez Yayıncılık.

Beck, U. (1992). Risk society: towards a new modernitiy. London: Sage.

Beck, U. (2008). World at risk. Camridge, UK: Polity Press.

Berger, P. ve Luckman, T. (2008). Gerçekliğin sosyal inşası bir bilgi sosyolojisi incelemesi. (1. bask1). (V. S. Öğütle, Çev.). Bursa: Paradigma. (Orijinal çalışma basım tarihi 1976).

Demir Özen, B. (2020). Salgının medikopolitiği. İstanbul: Nota Bene Yayınları.

Erşen, E. (2020). Koronavirüs, küreselleşme ve uluslararası sistem. U. Ulutaş (Ed.), Covid-19 sonrası küresel sistem: Eski sorunlar, yeni trendler (1. baskı) içinde (s. 58-61). Ankara: Sam Yayınları.

Fichter, J. H. (2019). Sosyoloji nedir? (4. baskı). (N. Çelebi, Çev.). Ankara: Anı Yayıncılık. (Orijinal çalışma basım tarihi 1964).

Ford, M. (2018). Robotların yükselişi: yapay zeka ve işsiz bir gelecek tehlikesi (1. bask1). (C. Duran, Çev.). İstanbul: Kronik. (Orijinal çalışma basım tarihi 2008).

Foucault, M. (2006). Kliniğin Doğuşu (1. baskı). (İ. M. Uysal, Çev.). Ankara: Epos Yayınları. (Orijinal çalışma basım tarihi 1963).

İşman, A. (2008). Uzaktan eğitim. Ankara: Pagem.

Özkan, Y. (2021, 17 Mart). Yeşil sertifika: AB vatandaşlarının serbestçe dolaşabilmesi için 'aşı pasaportu' uygulaması geliyor. BBC News Türkçe. https://www.bbc.com/turkce/haberler-dunya-56426077

Smith, A. (2011). Toplumsal değişme anlayışı (1. baskı). (Ü. Oskay, Çev.). İstanbul: Gündoğan Yayınları. (Orijinal çalışma basım tarihi 1984).

Williams, R. (1983). Culture and society, 1780-1950 (1. bask1). New York: Columbia University Press. 